\title{
Short Communication: Muscle protein bands resolved by Sarotherodon melanotheron from fresh and brackish water habitats
}

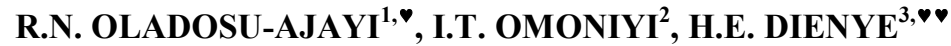 \\ ${ }^{1}$ Department of Fisheries Technology, Federal College of Freshwater Fisheries Technology (FCFFT). New Bussa. Niger State, Nigeria. "email: \\ oladosuajayi@gmail.com \\ ${ }^{2}$ Department of Aquaculture and Fisheries Management, Federal University of Agriculture. Abeokuta, Ogun State, Nigeria \\ ${ }^{3}$ Department of Fisheries. University of Portharcourt, Rivers State, Nigeria. `email: henrydienye@gmail.com
}

Manuscript received: 30 September 2017. Revision accepted: 19 February 2018.

\begin{abstract}
Oladosu-Ajayi RN, Omoniyi IT, Dienye HE. 2018. Muscle protein bands resolved by Sarotherodon melanotheron from fresh and brackish water habitats. Nusantara Bioscience 10: 41-46. An electrophoretic analysis of muscle protein of Sarotherodon melanotheron from freshwater (Eleiyele Reservoir, Ibadan, Nigeria) and brackish water (Lekki Lagoon, Lagos, Nigeria) was carried out using the Sodium Dodecyl Sulphate Polyacrylamide Gel Electrophoresis (SDS-PAGE). The protein banding patterns for the fish species were distinguishable. The freshwater $S$. melanotheron samples displayed 15-22 protein bands with the male samples having the highest while the brackish water $S$. melanotheron samples displayed 13-20 protein bands with the female having the highest. The freshwater $S$. melanotheron were also observed to have resolved a higher range of protein bands of molecular weights ranging between $20 \mathrm{kd}$ to $99 \mathrm{kd}$ than the brackish water species, which resolved protein bands of lower molecular weights ranging between $20 \mathrm{kd}$ to $95 \mathrm{kd}$. The electrophoretic analysis of muscle proteins revealed that SDS-PAGE can be considered a good taxonomic criterion to differentiate among and within fish species.
\end{abstract}

Keywords: Brackish water, electrophoresis, freshwater, muscle protein, molecular weight, protein band, Sarotherodon melanotheron

\section{INTRODUCTION}

Fish is a primary source of animal protein to nutritionally low standard nation including Nigeria. In spite of the fact that Nigeria is rich in fishery resources, it appears to be inadequate in animal protein supply because it has not been able to meet the standard FAO recommendation of $70 \mathrm{~g}$ protein consumption, $50 \%$ of which should be of animal origin (Ephraim 2005). Inland fishery contributes to a significant portion of the total fish catch in Ghana. The fisheries sector is one of the key sectors in Ghana, employing more than 2 million people directly or indirectly (Fisheries Commission 2011). Abban et al. (2004) noted that in Africa, tilapias are among the most commercially and thus socioeconomically important inland fish Tilapia is a large genus in Family Cichlidae (cichlids), which refer to Nelson (2006) is the third largest fish in the world and one of the most diverse fish species. Tilapia has a relatively short generation time of about six months and it is suitable for investigation of the application of genetics in aquaculture from conservation of genetic resources. They breed in captivity and are enjoying wide acceptance as food fish because of their high palatability (Usman et al. 2013). Sarotherodon melanotheron is cichlid that occurs commonly in West Africa and supports a major fishery in lagoons. Ephraim (2005) reported that in Nigeria, specimens of $S$. melanotheron were found to have escaped during a high flood from an experimental pond into a small freshwater reservoir within the University of Ibadan where they have successfully established themselves.

Sarotherodon melanotheron is a demersal (bottomassociated) species inhabiting fresh to brackish water where it occurs. It is a tropical West African native occurring from Senegal to Congo and southern Cameroon (Trewevas 1983; Robbins et al. 1991). The species is common in quiet muddy backwater habitats, where aquatic vegetation is abundant (Jennings and Williams 1992). Outside of its native range, blackchin tilapia have been introduced to several countries across Asia, North America, and Europe (Wohlfarth and Hulata 1983). Blackchin tilapia have been reported to reach $28 \mathrm{~cm}$ standard length (SL) (Olaosebikan and Raji 1998). In Florida, they commonly attain $22 \mathrm{~cm}$ standard length and $24 \mathrm{~cm}$ SL is possible (Hensley and Courtenay 1980; Finucane and Rinckey 1964). Blackchin tilapia have been exploited as a food resource in their native range, and have been utilized as aquaculture and non-native fishery species elsewhere as well (Springer and Finucane 1963).

Taxonomic study of fish species occurring in each area is an essential pre-requisite to broad programme of genetic resource preservation. Therefore, knowledge of genetic characters of fish is important and can be got from the use of biological genetic methods that have been used to examine relationships among related animal species. This is because of the direct relationship between muscle protein and gene (Ephraim 2005). Thus, gel electrophoresis has become a veritable tool for studying variations at the genetic level as well as establishing phylogenetic trees. 
Electrophoresis is a separation technique closely associated with chromatography, which operates on the basis that focuses on the mobility of the charged molecules under the influence of an electric field towards the electrodes and migration of molecules of different sizes or charges at different velocities. In polyacrylamide gel electrophoresis (PAGE), proteins migrate in response to an electrical field through pores in a polyacrylamide gel matrix; pore size decreases with increasing acrylamide concentration of pore size and protein charge, size shape determines the migration rate of the protein. $S$. melanotheron from fresh and brackish water habitats have been observed to be phenotypically separable populations (Omoniyi and Agbon 2004). Hence, this study aims to analyze the muscle protein of $S$. melanotheron from both habitats and know which protein bands are common to them as well as the ones that make them differ from each other.

\section{MATERIALS AND METHODS}

\section{Description of study sites}

The study was carried out in Eleiyele Lake (freshwater habitat) in Ibadan, Oyo State, and the Lekki Lagoon (brackish water habitat) in Lagos State, Nigeria (Figure 1). Eleiyele lake is located in Ibadan at an altitude of $125 \mathrm{~m}$ above sea level. It was formed by damming the Ona River which is part of the dense network of inland watercourses that flow Southwards into Lagos. It has an area of $5.46 \mathrm{~km}^{2}$ with a storage capacity of 70,460 x $10^{6}$ liters. Lekki lagoon is located in Lagos which is bounded south by the Gulf of Guinea (from $246^{\circ} 55^{\prime}$ to $430^{\circ} \mathrm{E}$ ); west in Benin Republic it is almost entirely free from rock, though often shallow, with numerous banks (Ephraim 2005).

\section{Collection of specimens}

Trips were made to each station at different times in June 2005. The type of gears employed in collection varied from one site to the other. At Eleiyele Lake, the fish specimens were obtained directly from fishermen (who used cast and set nets). These were then transported in ice to keep them in good condition even after death during the trip and preserved in the deep freezer before treatment at a later date. The specimens from Lekki lagoon were from the fishmongers who bought from the local fishermen. Though, they were dead, the ones in the pre-rigor stage were picked (freshly killed) and also transported like the former. The fish used for the study had total length (TL) ranges of 14$17 \mathrm{~cm}$ (Eleiyele) and 19-20 cm (Lekki).

\section{Electrophoresis protocol}

\section{Preparation of separation gel}

The separation gel was made from the already prepared stock solutions stored in the refrigerator. It was prepared by polymerizing a reagent, Methylene bisacrylamide in the presence of a catalyst, Ammonium persulphate (APS). Tetramethylene diamine (TEMED) was also present to initiate and control polymerization. $4 \mathrm{~mL}$ TEMED solution was introduced into the running tubes with a pipette a layer of $0.5 \mathrm{~mL}$ of ethanol was introduced over the gel solution and gradually pressed to release the ethanol until a layer of ethanol is formed with sharp interphase with the gel solution. The layer of ethanol ensured a flat surface and excluded oxygen which could inhibit polymerization. The gel polymerized within 45 minutes. The ethanol was drained by holding the gel stand upside down on an absorbent paper and thereafter rinsed with distilled water.

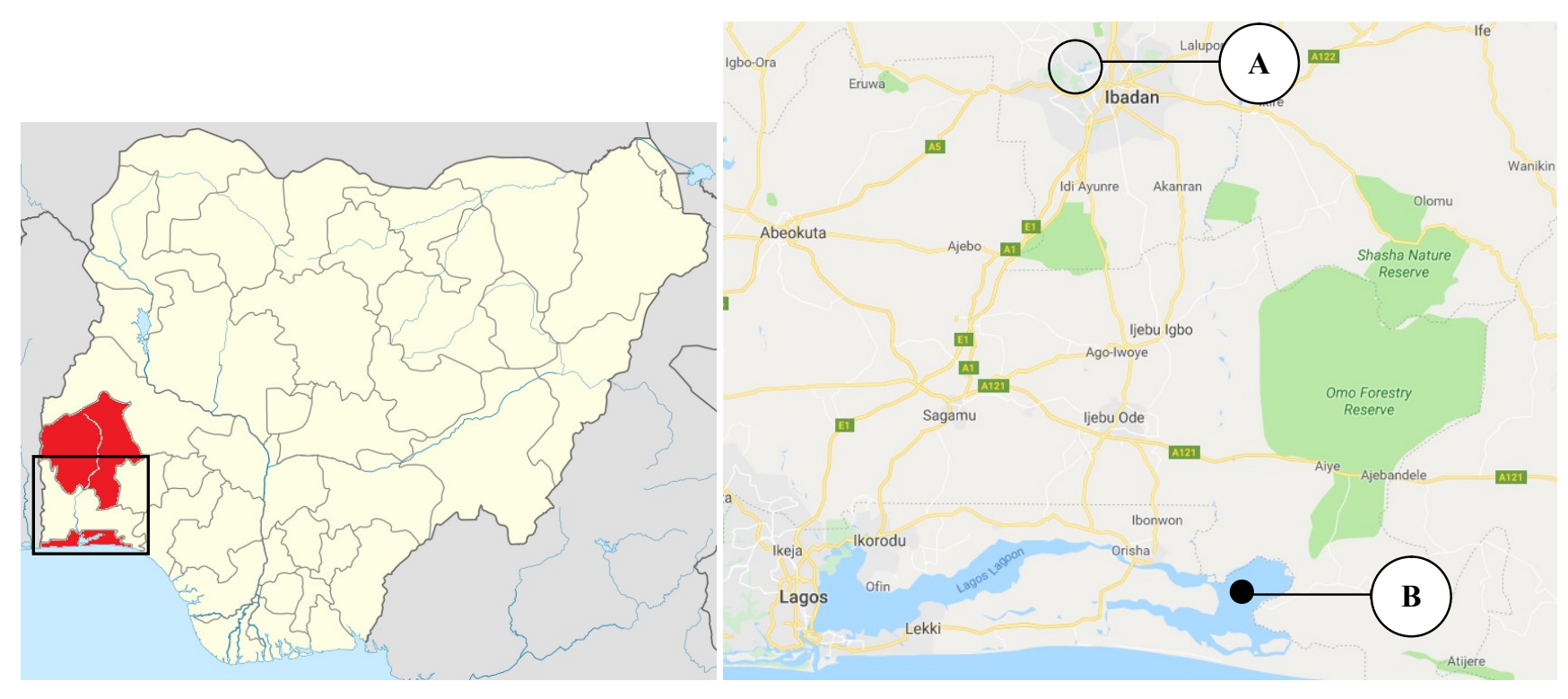

Figure 1. Area study in southwest Nigeria. A. Eleiyele Lake (freshwater habitat) in Ibadan, Oyo State, B. Lekki Lagoon (brackish water habitat) in Lagos State 


\section{Preparation of stacking gel}

This was prepared by polymerizing acrylamide and methylene bis acrylamide in the presence of a catalyst APS.TEMED was also added to initiate and control polymerization. Immediately after preparation, the gel solution was introduced into the running tubes on top of the separation gel after inserting the well combs in between the glass plates. A layer of distilled water was added and the gel polymerized after 45minutes. After complete polymerization, the water was drained off on an absorbent paper and wells combs removed.

\section{Preparation of fish sample}

While the stacking gel was allowed to polymerize, a small piece of fresh skeletal muscle $(2 \mathrm{~g})$ of fish was collected with a knife and put in a mortar. $50 \mu \mathrm{l}$ distilled water was added and ground manually with a glass rod. 20 $\mu \mathrm{l}$ of the crude homogenate of each sample was mixed with sample buffer (loading buffer at a ratio of 1:4). All the samples were heated for five minutes at $95^{\circ} \mathrm{C}$ to denature the protein and cooled in ice. $10 \mu \mathrm{l}$ of each sample was pipetted into each well with a long-tipped micropipette.

\section{Electrophoresis}

The buffer solution made of $6.0 \mathrm{~g}$ of Tris hydroxymethyl aminomethane (Tris), $28.8 \mathrm{~g}$ of Glycine and $100 \mathrm{~mL}$ of distilled water was prepared and put in the refrigerator. $70 \mathrm{~mL}$ of the resultant solution was diluted 5 times with distilled water, $150 \mathrm{~mL}$ and $250 \mathrm{~mL}$ were poured into the lower and upper chambers of the electrophoresis equipment respectively. The running tubes were fitted into upper chamber and $1 \mathrm{~mL}$ of bromophenol blue was added to the upper chamber. The apparatus was covered with a lid with electrode assembly. The positive lead from the stabilized power supply unit was connected to the lower electrode and the negative lead to the upper electrode on the lid. The power supply unit was switched on and made to deliver $110 \mathrm{v}$ to each of the running tubes for 90 minutes.

\section{Removal of gels}

The gel column was removed with a $10 \mathrm{~mL}$ hypodermic syringe filled with water. The running tube was rotated while water was being discharged through a syringe working gradually upwards until the gel was separated from the tube wall by a film liquid.

\section{Staining and destaining}

The gels were stained in Coomassie brilliant blue for 4 hours and destained or counterstained with $7 \%$ acetic acid for 24 hours. The stained protein bands were expressed qualitatively by number, migration distance, and staining intensity.

\section{Gel viewing}

The destained gels were viewed under the ultra-violet light to set the protein bands as well as the intensely stained bands.

\section{Gel documentation}

The gels were documented using the Polaroid camera to take the electropherograms

\section{Data analysis}

The experiments were performed in triplicate with oneway analysis of variance (ANOVA) using SPSS software (12.0 for Windows; SPSS Inc., Chicago, IL., U.S.A.) to reveal differences among treatments. Dunnett's post test was used to determine the detection limit by comparing differences in protein bands readings between the baseline and the laboratory-adulterated samples. All data were obtained at least in triplicate and experiments were repeated twice. Statistical significance was accepted at $\mathrm{P}=0.05$.

\section{RESULTS AND DISCUSSION}

\section{Sodium Dodecyl Sulphate Polyacrylamide Gel Electrophoresis}

Plate 1 presents the muscle protein electropherograms of $S$. melanotheron from the fresh and brackish water habitats. The protein markers with their corresponding molecular weights run as standard are shown in Table 1. The relative molecular weights of resolved protein bands of the analyzed muscle shown in Table 1 were calculated from the migration distance (the ratio of the distance moved by the marker to the total distance moved by the tracking dye). The Table 1 also shows that relative molecular weights of the analyzed muscle protein ranged from 20000 Daltons $(20 \mathrm{kd})$ to 99000 Daltons $(99 \mathrm{kd})$ in all the $S$. melanotheron analyzed. It was also observed that the muscle protein migrated further than the standard protein marker used.

\section{Muscle protein in male Sarotherodon melanotheron from the freshwater habitat}

Protein bands observed in the muscle proteins of the male $S$. melanotheron from freshwater had relative molecular weights ranging from $20 \mathrm{kd}$ to $99 \mathrm{kd}$. The bands were different in number $\left(\mathrm{MF}_{1}=20, \mathrm{MF}_{2}=22, \mathrm{MF}_{3}=15\right)$ as well as in their position resolved along the gel. $\mathrm{MF}_{2}$ resolved proteins of a higher relative molecular weight than $\mathrm{MF}_{1}$, followed by $\mathrm{MF}_{3}$ (Columns $\mathrm{A}, \mathrm{F}$, and $\mathrm{D}$ in Table 1 ).

\section{Muscle protein in female Sarotherodon melanotheron from the freshwater habitat}

The female $S$. melanotheron resolved between 20-21 protein bands with molecular weights ranging between 20 $\mathrm{kd}$ to $95 \mathrm{kd}$. The relative positions in the two females were not identical with $\mathrm{FF}_{2}$ having a higher range than $\mathrm{FF}_{1}$ (Columns B and I in Table 1).

\section{Muscle protein in male Sarotherodon melanotheron from the brackish water habitat}

Columns $\mathrm{E}$ and $\mathrm{G}$ in Table 1 revealed that 18 and 17 bands of muscle protein occurred in $\mathrm{MB}_{1}$ and $\mathrm{MB}_{2}$ respectively (Table 2). The relative molecular weight showed between $20 \mathrm{kd}$ to $99 \mathrm{kd}$. The relative position of 
these bands along the gel was different with $\mathrm{MB}_{1}$ resolving proteins of a higher molecular weight than $\mathrm{MB}_{2}$.

\section{Muscle protein in female Sarotherodon melanotheron from the brackish water habitat}

Thirteen to twenty muscle protein bands were resolved in the female $S$. melanotheron from brackish water. The relative molecular weight showed between $2 \mathrm{kd}$ to $99 \mathrm{kd}$. The relative positions of these bands in the female from brackish water differ greatly with $\mathrm{FB}_{1}$ resolving much higher range protein than $\mathrm{FB}_{2}$ and $\mathrm{FB}_{3}$ (Columns $\mathrm{C}, \mathrm{H}$, and $\mathrm{J}$ in Table 1).
Table 2. Muscle protein bands resolved by Sarotherodon melanotheron of fresh and brackish water habitats

\begin{tabular}{lcc}
\hline & Brackish water & Freshwater \\
\hline Male 1 & 18 & 20 \\
Male 2 & 17 & 22 \\
Male 3 & - & 15 \\
& & \\
Female 1 & 20 & 20 \\
Female 2 & 13 & 21 \\
Female 3 & 15 & - \\
\hline
\end{tabular}

Table 1. Relative molecular weight of the analyzed protein bands of Sarotherodon melanotheron from fresh and brackish water habitats relative molecular weights (daltons)

\begin{tabular}{lcccccccccc}
\hline Marker & $\mathbf{M F}_{\mathbf{1}}$ & $\mathbf{M F}_{\mathbf{2}}$ & $\mathbf{M F}_{\mathbf{3}}$ & $\mathbf{F F}_{\mathbf{1}}$ & $\mathbf{F F}_{\mathbf{2}}$ & $\mathbf{M B}_{\mathbf{1}}$ & $\mathbf{M B}_{\mathbf{2}}$ & $\mathbf{M B}_{\mathbf{3}}$ & $\mathbf{F B}_{\mathbf{1}}$ & $\mathbf{F B}_{\mathbf{2}}$ \\
\hline 66000 & 99000 & 99000 & 99000 & 95000 & 92000 & 99000 & 92000 & 72500 & 95000 & 99000 \\
45000 & 92000 & 93000 & 92000 & 87000 & 87000 & 92000 & 81000 & 68000 & 92000 & 87000 \\
36000 & 80000 & 84500 & 76000 & 79000 & 83500 & 83500 & 73000 & 64000 & 87000 & 76000 \\
29000 & 76000 & 79000 & 64000 & 71000 & 79000 & 76000 & 59000 & 57500 & 81000 & 71000 \\
24000 & 72500 & 72500 & 54000 & 66000 & 76000 & 66000 & 52500 & 54000 & 73000 & 52500 \\
20100 & 57500 & 68000 & 45000 & 60000 & 68000 & 60000 & 43000 & 43000 & 58000 & 45000 \\
& 52000 & 64000 & 36000 & 52000 & 64000 & 54000 & 36000 & 40000 & 53000 & 38500 \\
& 47000 & 58000 & 34000 & 45000 & 58000 & 66500 & 34000 & 37000 & 47000 & 29000 \\
& 41000 & 53000 & 31000 & 38500 & 52000 & 34000 & 33000 & 33000 & 41000 & 27000 \\
& 36500 & 45000 & 28000 & 36500 & 47000 & 31500 & 31000 & 31500 & 36000 & 24000 \\
& 36000 & 38000 & 25000 & 33000 & 37000 & 31000 & 29000 & 28000 & 34000 & 21500 \\
& 31500 & 36500 & 22000 & 31000 & 36000 & 28000 & 27000 & 25500 & 32000 & 20500 \\
& 31000 & 34000 & 21000 & 28000 & 34000 & 23500 & 22000 & 24000 & 31000 & 20000 \\
& 28000 & 33000 & 20200 & 25500 & 32500 & 22000 & 21000 & 20200 & 28000 & 23800 \\
& 24000 & 31000 & 20000 & 24000 & 28000 & 23000 & 20500 & 20000 & 24000 \\
& 23000 & 28000 & & 23000 & 25500 & 20500 & 20200 & & 22000 \\
& 22000 & 27000 & & 22000 & 24000 & 20200 & 20000 & & 20500 \\
\end{tabular}

Note: $\mathrm{MB}=$ Males from brackish water, $\mathrm{FB}=$ Female from brackish water, $\mathrm{MF}=$ Males from fresh water, $\mathrm{FF}=$ Females from freshwater

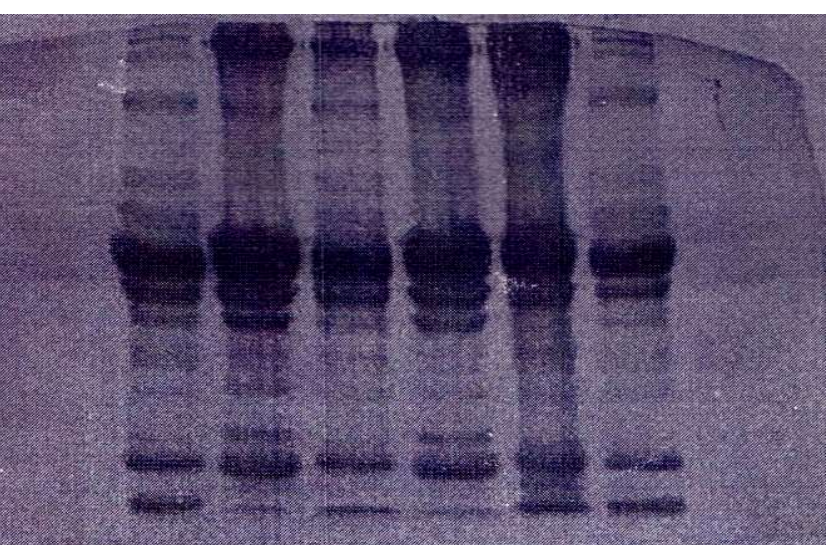

LRM MF2 FF2 MB3 $\quad$ MF3 $\quad$ MB1 $\quad$ MF1 $\quad$ MRM

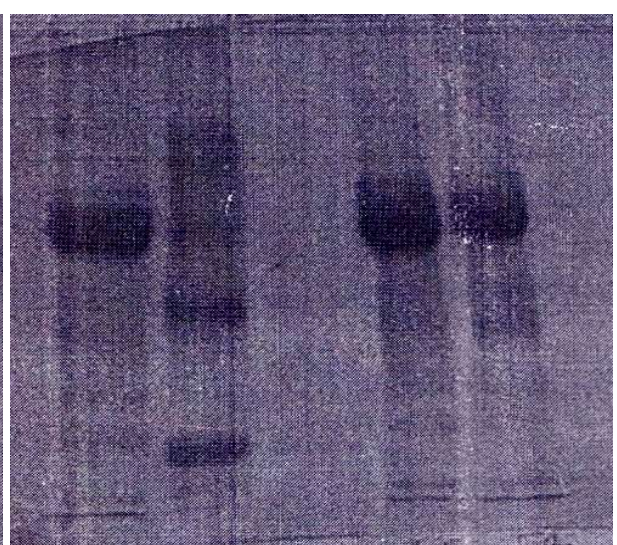

MB2 FB1 MRM FF1 FB2

Plate 1. Electropherograms of the analyzed protein muscle. MB: Males from brackish water, FB: Female from brackish water, MF: Males from fresh water, FF: Females from fresh water, LRM: Low range marker, MRM: Middle range marker 


\section{Discussion}

The SDS-PAGE pattern in Plate 1 shows that there were fifteen to twenty-two protein bands resolved in the $S$. melanotheron of the freshwater habitat (Table 2) out of which both sexes shared in common the low band of $28 \mathrm{kd}$ and $21 \mathrm{kd}$ and the terminal band of $20 \mathrm{kd}$. This is in agreement with the findings of Ufuk and Bilal (2007) where he discovered by SDS-PAGE that 16 protein bands were diagnostic for Channa gachua and Channa striatus, 10 bands for $C$. marulus and 15 bands for $C$. punctatu which falls within the range reported in this study. These data showed that the total number of skeletal muscle protein bands could vary among classes, species, or subspecies. S. melanotheron of the brackish water habitat also showed that there were thirteen to twenty protein bands out of which both sexes shared in common the low bands of $20.5 \mathrm{kd}$ and $20.2 \mathrm{kd}$, and the terminal band of 20 $\mathrm{kd}$ which is in agreement with the findings of Hasnain et al. (2005) used skeletal muscle differentiation in their study on 4 species of the genus Channa and they reported that different fish species had different numbers of skeletal muscle protein bands. The protein bands common to the $S$. melanotheron of each habitat show that they were of the same genus while the terminal band of $20 \mathrm{kd}$ that is common to all the fish from both habitats depicts their family resemblance. The males from the freshwater and brackish habitats were similar in that they both resolved the protein band of $31 \mathrm{kd}$ apart from the terminal band of $20 \mathrm{kd}$ with the males recording a higher protein band, while the female from the freshwater and brackish water habitats also shared in common the bands of $87 \mathrm{kd}, 28 \mathrm{kd}, 24 \mathrm{kd}$ and $20.5 \mathrm{kd}$ apart from the terminal $20 \mathrm{kd}$ band also with the males recording a higher protein band. The recoded data are in agreement with the findings of (Sallam et al. 2006) in that males of E. massavens is recorded highest protein levels in their muscles compared to their females.He attributed the decrease of protein content in females as the result of gonads and digestive gland of females have the ability to mobilize reserves from the muscle tissue to the gonads to meet the demands of the reproductive process. In this respect, another hypothesis was suggested by Kyomo (1998), Jeck et al. (1989), and Rosa and Nume (2003). They attributed the significant differences between the muscle protein content of female and male crustaceans due to males do not invest much energy for reproduction per se, but rather use most of it for somatic growth, i.e., males have lower energetic requirements than females to form a fully developed gonad

The difference in the migration distance of the bands of different molecular weights could also suggest the parental stock variation and sex-linked differences. This to an extent tends to agree with the report of Ephraim (2005) on the protein electrophoresis, meristic and morphometric parameters in the racial studies of commercial fish species off the Nigerian coast. The observed protein bands' mobilities were similar, in contrast to that of the analyzed $S$. melanotheron whose mobilities were different. Furthermore, the muscle proteins were a mixture of low and high molecular weights. The standard protein markers showed variation in number and positions according to sexes, which enabled easy identification and differentiation. In $S$. melanotheron of freshwater habitat, higher range of protein bands was resolved than in the $S$. melanotheron of the brackish water habitat. This observation thus corroborates Omoniyi and Agbon (2004) that reported the freshwater $S$. melanotheron broodstock to be preferable to the brackish water $S$. melanotheron to have resolved proteins of higher molecular weights could also be traced to some environmental factors and spatial habitat differences such as temperature, salinity, and substratum of the two water bodies.

\section{Conclusion}

Although, the use of traditional morphometric and meristic analysis delineates taxonomic relationships, there is need to employ a biochemical approach because of the biases from these measurements in some areas of the body and expression of these features being environmentally affected, often render the method alone to fail distinguishing groups differing at sub-specific level. Electrophoresis techniques appear to be the most useful and reliable tool to characterize fish species since ability in expression of most protein is determined by genetic processes. Comparatively, the freshwater stock of $S$. melanotheron had more protein bands than its brackish water counterpart. The protein bands resolved in the freshwater $S$. melanotheron samples were of higher molecular weights than the brackish water sample with the males resolving higher range of protein band than the females. Conclusively, the freshwater $S$. melanotheron is more deeply bodied in terms of the protein band constituent than its brackish water counterpart, which thus recommends it for breeding programmes.

\section{Recommendation}

This study in its bid to answer the call made by Omoniyi and Agbo (2004) to analyse biochemically in order to explain and confirm the genetic basis of the variations observed in $S$. melanotheron from fresh and brackish water habitats (Awba Reservoir and Lagos Lagoon) has been able to identify the one with a higher range of protein bands. To this end, it is therefore recommended that the reproduction of $S$. melanotheron aspect through hybridization be explored. For example the freshwater male sample which displayed more protein bands can be crossed with the female from the brackish water, and the hybrid biochemically analyzed to see the number and resolution of protein bands that it would display. Also, the ever-increasing demand for fresh fish protein in Nigeria as a result of both increase in population and a decline in beef production could be taken care of by the cichlid industry because of its short generation time and the members' ability to readily breed in ponds.

\section{REFERENCES}

Abban EK, Agyakwah S, Falk TM. 2004. Socio-economic importance of Tilapiine fishes. In Abban EK, Casal CMV, Falk TM, Pullin RSV (eds.). Biodiversity, Management, and Utilization of West African 
Fishes, World Fish Center Conference Proceedings, Penang, Malaysia.

Ephraim RN. 2005. Electrophoretic Analysis of Muscle Protein of Sarotherodon melanotheron (Ruppell) From Freshwater and Brackish water Habitats in Nigeria. University of Agriculture, Abeokuta (UNAAB) Ogun State, Nigeria.

Finucane JH, Rinckey GR. 1964. A study of the African cichlid, Tilapia heudeloti Drumeril, in Tampa Bay, Florida. Proceedings of the Annual Conference of the Southeastern Association of Game and Fish Commissioners 18: 259-269.

Fisheries Commission. 2011. Annual report. Ministry of Food and Agriculture, Ghana.

Hasnain A, Hasan AS, Ahmad R, Pandey RB. 2005. Identification of species - marker bands in native and SDS-PAGE patterns of soluble muscle proteins of four species of Genus Channa (Channidae: Channiformes) with evidence of some intraspecies heterogeneity. Asian Fish Sci 18: 49-58.

Hensley DA, Courtenay Jr WR. 1980. Tilapia melanotheron (Ruppell) Blackchin Tilapia. In: Lee DS, Gilbert CR, Hocutt CH, Jenkins RE, McAllister DE, Stauffer JrJR (eds.). Atlas of North American Freshwater Fishes. North Carolina State Museum of Natural History, Special Publication 1980-12 of The North Carolina Biological Survey, Raleigh, NC, USA

Jeckel WH, Moreno JE, Moreno VJ. 1989. Biochemical composition, lipid classes and fatty acids in the male reproductive system of the shrimp Pleoticus muelleri bate. Compar Biochem Physiol 93B: 807811.

Jennings, DP, Williams JD. 1992. Factors influencing the distribution of blackchin Tilapia Sarotherodon melanotheron (Osteichthyes: Cichlidae) in the Indian River system, Florida. Northeast Gulf Science 12: 111-117.

Kyomo J. 1998. Analysis of the relationship between gonads and hepatopancreas in males and females of the crab Sesarma intermedia, with reference to resource use and reproduction. Mar Biol 97: 87-93.

Nelson JS. 2006. Fishes of the World. John Wiley and Sons, Inc., New York.
Olaosebikan BD, Raji A.. 1998. Field guide to Nigerian freshwater fishes. Federal College of Freshwater Fisheries Technology, New Bussa, Nigeria.

Omoniyi IT, Agbon AO. 2004. Morphometric Variations in Sarotherodon melanotheron (Pisces: Cichlidae) From Brackish and Freshwater Habitats in South Western Nigeria. Proceeding of the $29^{\text {th }}$ Annual Conference of the Genetic Society of Nigeria, Abijan, Nigeria.

Robins CR, Bailey RM, Bond CE, Brooker JR, Lachner EA, Lea RN, Scott WB. 1991. World fishes important to North Americans. Exclusive of species from the continental waters of the United States and Canada. Am Fish Soc Spec Publ 21: 243.

Rosa R, Nunes ML. 2003. Biochemical composition of deep-sea decapod crustaceans with two different benthic life strategies off the Portuguese south coast. Deep-Sea Res I 50: 119-130.

Sallam WS, Temraz TA, Gabar HR. 2006. Biochemical compositions and heavy metals accumulation in some commercial crustaceans from the Mediterranean coast off Port Said, Egypt. J Egypt Ger Soc Zool 51 D: 127-14.

Springer VG, Finucane JH. 1963. The African cichlid, Tilapia heudeloti Dumeril, in the commercial fish catch of Florida. Trans Amer Fish Soc 92: 317-318.

Trewevas E. 1983. Tilapiine Fishes of the Genera Sarotherodon, Oreochromis and Danakilia. British Museum of Natural History Publ Num 878. Comstock Publishing Associates. Ithaca, New York.

Ufuk B, Bilal K. 2007. Comparison of skeletal muscle protein bands among five populations of Bufo viridis in Turkey by SDS-PAGE. Turkish J Zool 31: 419-422.

Usman BA, Agbebi OT, Bankole MO, Oguntade OR, Popoola MO. 2013. Molecular characterisation of two cichlids populations (Tilapia guineensis and Sarotherodon melanotheron) from different water bodies in Lagos State, Nigeria. Intl J Biotechnol Mol Biol Res 4 (5):. 71-77.

Wohlfarth GW, Hulata G. 1983. Applied genetics of tilapias. ICLARM Stud Rev 6: 26. 